\title{
Reflections on the Mental Health Education of Contemporary Undergraduates in Police Colleges
}

\author{
Xiaohong Zhang \\ Hunan Judicial Police Vocational College \\ Changsha, China 410131
}

\begin{abstract}
Police colleges are cradles of police cultivation, and most graduates from police colleges are educated to be police, therefore, student quality in police colleges will have a direct influence on the whole quality of police teams. Mental health plays an important in educating students studying in police colleges, which is a special requirement for being police. Students in police colleges are required to have mental health, yet currently the mental health conditions of students in police colleges are not as good as expected. Thus, it has become an urgent and significant mission for police colleges to intensify mental health education and fully improve the mental health level of students in police colleges.
\end{abstract}

Keywords-police college; college students; mental health; education

\section{INTRODUCTION}

Compared to other countries, China is in a great lack of police for front line work, and police have to endure long term overload work and the police team has to face a situation with the highest injures and most death in the time peace, which keep them in a now and then spirit of tension and fatigue. After being in the situation for a long time, it will easily cause mental problems. Accordingly the mental quality of being police shall have common mental characteristics shared by the society and special professional mental quality as well. Students in police colleges are main backup for future police. And targeted education shall be launched in police colleges on mental quality of students in order to improve the mental quality of their own and solve the mental problems of police in sources.

\section{Main PRoblems In Mental EdUCATION OF STUDENTS IN POLICE COLLEGES}

\section{A. Neglect of Mental Education Environment}

Mental education environment: It is defined to be conditions and atmosphere that college culture environment, teaching activities, teacher-student relations have effect on students' mental health. Police colleges should make full of advantageous conditions of their own, exploit potentials and create appropriate conditions for mental education, forming features of their own. However, the facts in police colleges are: focus on construction of systems, neglect that comfortable environment atmosphere; focus on uniform policing or military management, neglect comfortable development of individual freedom, which have seriously been barriers for improving whole efficiency of mental education.

\section{B. Neglect Characteristics of Police Vocational Education Having no Features in Course Construction}

Courses are not only main information sources for students during teaching activities but also basic foundation for teachers' teaching design. Among diverse contradictions in teaching, the solution of contradictions related to courses is the key to improve teaching effect. Course reform cannot be achieved though a decision, which is gradually advancing with technical development. During the implementation of overall concept reform and experimental strategy, the course reform plays a vital role, to renew course contents and forms and set up a logical course structure is still the key point for teaching reform in the country. Textbooks are first carriers for student mental health education in police colleges, and whether textbooks are feasible or not will bring a direct effect to the teaching effect. However, most mental health textbooks in police colleges pay little attention to the particularity of police vocational education, which contains basic no contents of police vocational education, and most textbooks used are general textbooks in colleges or universities, as a result of that, the knowledge of student mental health education in police colleges is generally plain, failing to the special needs of police vocational education.

\section{Neglect the Particularity of Police Vocational Education and the Construction of Mental Counselor Teams}

Based on actual channels of mental education in police colleges, to launch the construction of professional mental teacher team is an important choice for now and future. Professional teachers and student instructors are teachers to carry out mental education on students in police colleges. Under the current management system in police colleges, students' individual development and mental health get little attention, and there are no necessary communication between students and instructors or class teachers, which should be stressed. There is some limit between management and students, and it is very difficult to keep harmonious, sometimes, in order to make it easy for management, the individualities of some have to be oppressed. Thus contradictions occur between management and students, common and individual. Instructors and class teachers should not thick mental health guidance is an additional trouble for them, and instead, they should take it as a great support to their tasks. 


\section{INTENSIFY TO IMPROVE MEASURES IN STUDENTS' Health EduCATion IN Police COLLEGES}

A. Educate Police College Students to Set up Correct World Outlook and View of Life, Hold a Right Attitude to Realize and Deal with the Reality, Able to Keep an Efficient Balance with the Objective World

In order to achieve the point, the basic method is to instruct college students to form logical world outlook and view of life, realistically realizing and making preparations for what they face. Only going as such, can college students scientifically analyze and calmly deal with all they will meet, which will help them keep proper psychic reaction, preventing any abnormal one. In the meantime, with right world outlook and view of life set up, the can come to know the value of being human and closely connect what the want with what the country and the people want, even they undergo setback or unfortunate in study, work or life, they still can act optimistically, full of confidence to overcome, rejecting any negative emotion, psychological burden which may affect their mental health

\section{B. Set Offer Mental Quality Courses and Establish Psychological Consult Service Agency}

Statistics show, college students of the time generally have few knowledge of psychology, knowing little about some mental blocks or illnesses, many diseases such as neurasthenia and depressive disorder often cause severe results due to lack of full knowledge and little attention paid. Therefore, it has a necessity to set up mental quality courses for college students, in addition, colleges should establish mental consultancy agencies, instructing and helping students form good mental quality. The Suggestions of Intensifying Work in Colleges released by Ministry of Education in 2001 pointed out that colleges should include contents of mental health education in moral education, arranging mental health education courses in moral education, and create conditions to set up elective courses, lectures and reports.

1) Implement psychological guidance at different levels: First, select moral and politics teachers for training in basic theory, method and testing technique related to psychological consultancy, making them be active among students, holding students' psychological status to discover students' discomfort in psychology, so as to offer necessary psychological guidance and help students to face through self adjustment. Second, concentrate on freshman education and graduate education. Each year, make a survey on freshmen's mental health through Mental Health Questionnaire, select those who have psychological symptoms to receive analysis and diagnosis at the psychological consultancy center. According to the face to face analysis, distinguish different problems and types, and then adopt corresponding measures to prevent in advance. For sophomores and junior students, set up special lectures such as study psychology, friend-making psychology, creation psychology, fall-in-love psychology, emotion trouble and psychological disorder and psychological adjustment methods on the basis of specific problems. With regards to graduates, holding the topic "brilliant life", focus on instructing them in career planning, job psychological adjustment, professional psychological preparation, career development and so on for psychological health education, and guide them to be socialized in an active attitude.

2) Diverse educational methods can be adopted to enable students to know whether they have psychological problems or diseases and how to prevent and correct: Media and means can be used such as wall newspaper, broadcast, TV, newspaper, booklets and so on for knowledge publicity and mental health knowledge spread. Going as such, students may initially know mental health status of their own, learning all kinds of living skills to improve abilities of seeking for mental health assistance.

3) Establish a psychological crisis interference joint mechanism for students: Main members shall include head teacher, instructor, parents, psychological assistance and consultancy agencies, social professional diagnosis institutions and so on. Any student who is found with psychological problems or crisis shall be earlier reported and interfered. If possible, hot lines can be released to the public for help students find solutions as soon as possible.

\section{Combination of Mental Health Education and Major Courses in Police Colleges}

Major courses will provide solid theoretical basis for police practicing in the future, and the mental health status will drive students to apply professional knowledge in work and grasp basic technique and skills for work. Therefore, during the major course teaching and solution of practical problems, we should intensify mental health education on students, which is a specific embodiment of penetrability principle.

\section{Help College Students form Good Inter-personal Relationships}

Everyone cannot be separated from the society, to communicate with others is a necessary way to socialize college students, and main characteristics for communication will happen between people. With the influence, every student accepts and introduces the behaviors, attitudes and values of others into what they have owned, so that they will be similar to others, realizing the goal of understanding suggestions, emotion and requests between each other.

\section{CONCLUSION}

Students in police colleges are backup teams of police in the future, their mental quality will directly influence the work quality as police in the future. In recent years, though mental health education has been carried out in police colleges, yet it is still in an initial stage, only to keep improving the education quality can meet the requirements on police development in a new century and solve diverse psychological problems arising due to difficulties or setback that college student meet in study, living and inter-personal communication. 


\section{REFERENCES}

[1] Song Xiaoming, Police Mental Health and Health Care [M] Beijing: Qunzhong Press, 2004, pp616-617.

[2] Qiang Wei, Mental Health Education on Students in Public Security Colleges [J] Journal of Jiangsu Police Officer College, 2004 (6), pp 198-199.

[3] Zhang Zhensheng, Modern Police Psychology, Chinese people's Public Security University Press, Version 1999.

[4] Liu Xiaoming, Xu Wenjie, Mental Quality Education on College Students, Jilin People's Press, Version 1997, pp137-139.

[5] Guan Meilin, Discussion on Mental Health Education on Students in Public Security Colleges [J] Journal of Beijing People's College, 2002(1)75.

[6] Su Lizeng, Research on Youth Mental Health Education, Teacher Education Research, 1992(3), pp19-23. 